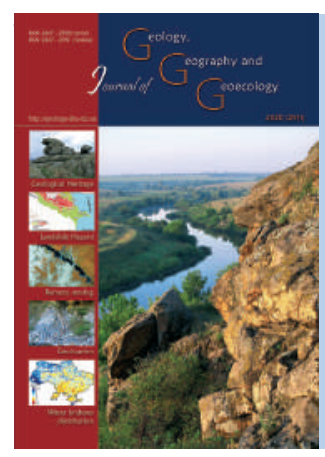

Yulia A. Olishevska

\section{Journal of Geology.} Geography and Geoecology

Journal home page: geology-dnu-dp.ua
ISSN 2617-2909 (print)

ISSN 2617-2119 (online)

Journ.Geol.Geograph.

Geology,

29(2), 364-376.

doi: $10.15421 / 112032$

\title{
Murals as the newest tourist resources: the case of Kyiv
}

\author{
Yulia A. Olishevska \\ Taras Shevchenko National University of Kyiv, Kyiv,Ukraine, jlia_29@ukr.net
}

Journ. Geol. Geograph. Geoecology, 29(2), 364-376.

Received: 03.12.2019

Received in revised form: 19.11.2019

Accepted: 17.01.2020
Abstract. The relevance of studying the murals is that the murals allow to diversify the tourist offer of the capital. The purpose of this publication is to analize the development of the murals and the opportunity of using them as a new type of tourism resource. One of the subjects of the study is to carry out a retrospective analysis of the existing collection of Kyiv's murals and to substantiate their use in the organization of excursion routes in order to inform tourists. During the study of the murals, the creation of the route allows to track the change in the image of the urban environment under the influence of street art. In the process of researching the murals as a tourist resources of cities, we have introduced the term "conceptual tourist resources", which in our opinion most accurately reflects their semantic charge. Murals are the alternative resources towards traditional tourism resources (natural, historical, cultural, socio-economical or socio-historical) that are widely used in the classifications of leading researchers in the tourism industry (Kvartal'nov V., Smal' I., Beidyk O., Mal's'ka M., Kuzyk S., Liubitseva O., Pankova Ye., Stafiichuk V., etc.). The study identified the 32 biggest murals in Kyiv and found that the murals are the relevant forms of street art that focuses on social, cultural, and historical topics. Mural paintings have been found to be motivating objects to visit and affect the formation of city's new symbols. In the route we have developed, we have selected 24 representative murals made in different styles, dedicated to several topics: milestones of Ukrainian history, the fight between good and evil, friendship and devotion, freedom and equality. Thus, the involvement of murals in excursion routes allows residents and guests of the capital city to track the change in the image of the urban environment under the influence of street art. In the course of the study, it was found that murals are ambiguously perceived in society. The analysis showed that the appearance of modern murals on the streets of the capital began in the mid-2000s, a sharp increase in their number occurred during 2015 - 2017. It was determined that the main factors that influenced the development of muralism in Ukraine were the demands of society and the organization of art festivals, including Muralissimo, City Art, Dynamic Urban Culture Kyiv, Mural Social Club, Art United Us, Mural Social Club Back to school! Ukraine, French Spring, etc. The largest art festivals include City Art 2015, Dynamic Urban Culture Kyiv 2015, Mural Social Club 2016, 2017, Art United Us 2016 , 2017, within which 88 works were created. The results of the study identified the trend in the development of muralism in Ukraine, which consists of the gradual change from spontaneous, anonymous street art to the development of concerted and commissioned by state bodies paintings, which are spread not only on the walls of industrial sites, residential buildings, but also on the walls of educational institutions, government institutions and the police department. Kyiv is the first city in the world where a mural was created on the walls of the police department. The study found that since the mid-2010, the murals began to establish in the central part of the city, and since 2014 they have spread to the so-called "gray" residential areas of Sviatoshyno, Darnytskyi, Desnyanskiy and Solomianskyi districts and Obolon', etc. Today, the total number of murals in the capital is 160.

Keywords: mural, urban habitat, tourism, tourist resources, street-art

\section{Мурали як новітні туристичні ресуриси (на прикладі міста Києва)}

\section{Ю.А. Олішевська}

\section{Київський національний університет імені Тараса Шевченка, Київ, Украӥна, jlia_29@ukr.net}

Анотація. Поряд із загальноприйнятими туристичними ресурсами інтенсивно відбувається пошук альтернативних, до яких належать сучасні арт-об'єкти, зокрема мурали, що дозволяють урізноманітнити туристичну пропозицію. Об'єктом дослідження є мурали міста Києва. На сьогодні мурали викликають протиріччя у наукових колах та $є$ виявом емоційних настроїв. Метою дослідження є характеристика розвитку муралів та можливість їх використання як альтернативного виду туристичних ресурсів. Основне завдання роботи - ретроспективний аналіз муралів Києва та обгрунтування їх використання для організації пізнавального туризму на основі розробленого екскурсійного маршруту, що дозволяє прослідкувати зміну образу міського середовища під впливом стріт-арту. Ретроспективний аналіз муралів міста Києва дозволив встановити, що поява сучасних муралів на вулицях столиці розпочалася з середини 2000-х років, різке зростання кількості муралів у Києві відбулося у період з 2015 по 2017 рр. Визначено, що головним чинником, який зумовив розвиток муралізму в Україн, стали 
мистецькі проекти, організовані з середини 2010 року. Найбільш масштабні арт-фестивалі, організовані в Україні це Миralissimo, City Art, Dynamic Urban Culture Kyiv, Mural Social Club, Art United Us, Mural Social Club Back to school! Ukraine. 3 усього різноманіття стінописів можна виділити мурали, створені у вигляді портретів відомих людей та діячів культури і мистецтва; присвячені актуальним проблемам людства: екологічній, боротьбі за свободу, рівність, любов, вмінню цінити людські стосунки та внутрішній світ кожного, умінню мріяти та цінувати життя і т. д. Художня креативність митців вуличного мистецтва змінює сучасний образ міст. Візуалізація соціально значущих проблем стає своєрідною візитівкою не лише столиці, але й інших українських міст.

Ключові слова: мурал, стріт-арт, туризм, туристичні ресурси, місто

Introduction. Nowadays, the forms of tourism resources are being diversified. Along with the common cultural, historical, natural, socio- economical resources, there is an intensive search for alternative resources for the diversification of tourist proposal. Some of these resources include various festivals, performances, modern art objects, in particular, murals.

Street art is often identified with graffiti, which may be considered as the origin of this art form. However, street art today covers much more varieties: graffiti, murals, mosaics, LED art, etc. The main feature of street art is content rather than form. The works of street art may be individual inscriptions or artists' initials, or they may have large sizes, such for example, as wall paintings called murals. Over the recent years, new applications are found for street art objects as alternative tourism resources.

Murals and street art itself mainly cause contradictory reactions in society and academia. Part of society treat them as works of art (Tylik, 2016), others as a spontaneous process of emotional manifestation. In particular, this opinion is shared by (Hrytsiuk, 2018), pointing to the origin of the first murals in Mexico as propaganda leaflets created by activists in the form of wall paintings in 1910-1917. Diego Rivera, David Alfaro Siqueiros, Jose Orozco, who are now considered to be muralism classics, created at that time.

It is impossible to imagine modern cities without murals. In Western Europe, muralism flourished in the 1980s, and it is now in its prime in Eastern Europe. Artists from different parts of the world actively paint Polish, Ukrainian, Slovak and Romanian buildings. While street art was in temporary decline in America in the 1980s, this movement started spreading almost in all European countries. The Berlin Wall became one of the largest art canvases in Europe. The Western side of the wall was all painted by German and international artists in the ' $80 \mathrm{~s}$ with most of the works having political and social implications (Bodnar, 2016), while the other side remained empty. Now there are several Ukrainian murals that are candidates for the largest ones in Europe. In January 2019, a series of murals with a total area of 560 sq.m. were created by Ukrainian artists at the "KLO" gas stations in Velyka Okruzhna street; they are candidates for the largest mural created at a gas station. Another large-scale project was created in 2016 on the wall of a 26-story building at the address: Maiakovskyy avenue, building $1 \mathrm{v}$. The author is an Italian artist working under the pseudonym " 2501 ". The main focus of the work is the encoded word "liberty".

Scientific sources mostly study historical aspects of the emergence and development of murals (Gastman, Neelon, 2011, Ganz, 2011, Bacharach 2015, Bodnar, 2016, Topol, 2016) and the influence of graffiti and murals on contemporary culture and art (Nguyen, Mackenzie, 2010, Shtep, 2010, Waclawek, 2011, Kuzova, 2015, Tylik, 2016, Havrylash, 2018. Havryliuk, 2018, Guinard, Margier, 2018, etc.); only few studies examine the influence of street art on the image of a city (Riggle, 2010, Moldoveanu, Franc, 2014, Omar, Sakip, Akhir, 2016, Guinard, Margier, 2018). Besides, there are discussions concerning the differentiation between the notions of street art, public art, monumental art, etc. (Bacharach 2015, Pilikin, 2018, Havrylash, 2018). The issue of using murals in tourism is understudied. However, there are examples of creating catalogues of street art works both for individual countries and individual artists (Shakter, 2018).

In Ukraine, the main source of information about the creation of new murals in different cities are messages in mass media, in particular, in TSN and "Vechirnii Kyiv" news outlets, an interactive map of Kyiv murals and the e-resource of the ZeFt.in.ua website; however, the scientific community does not pay enough attention to the study of murals and their use as tourism resources. Individual articles and media messages are mostly related to art projects Muralissimo, French Spring, Dynamic Urban Culture Kyiv, Mural Social Club, Best Street Art 2017, Mural Social Club. Back to school! Ukraine etc. It can be stated that nowadays the issue of street art development and the use of modern art objects in tourism is underexposed in the scientific literature, which contributes to the relevance of the present research.

The aim of the study is to describe mural development process and the potential of using murals as a new type of tourism resources. 
The main objective of the study is to conduct retrospective analysis of Kyiv murals and justify their use for the organization of educational tourism based on the designed excursion itinerary that would trace changes in the urban environment under the influence of street art.

Murals are alternative resources related to traditional tourism resources (natural, historical, cultural, socio-economical or socio-historical) which are commonly used in the classifications of prominent tourism researchers (Kvartal'nov I, Smal' I, Beidyk O, Mal's'ka M, Kuzyk S, Liubitseva O, Pankova Ye, Stafiichuk V., etc.). The complexity is also due to the varied perception of murals in society and in the scientific community. Up to now, there is a scientific discussion concerning the definition of the notions of street art, monumental art, etc., which complicated the process of the identification of mural as a separate art form and its differentiation as a tourism resource. We believe that it is worth using murals as new alternative attractions during city excursions.

Thus, the use of such objects complements the existing classifications of tourism resources. It is reasonable to ascribe murals to conceptual resources, which best reflects their essence. Disputable issues concerning the differentiation between the notions of street art, monumental art, public art and mural proper cannot influence the fact that murals do exist and their number in the world and in Ukraine is increasing every year.

Materials and methods. Research on murals is mainly situated in the culturological plane, and there have not been many studies of murals from the geographical perspectives; therefore, in this study we operate the retrospective analysis toolkit and the method of Kyiv mural inventory by using an information resource, an interactive map of Kyiv, the ZeFt website of Ukraine's landmarks, and Ukrainian online mass media (ukrinform, tsn.ua, kiev.informator, vechirnij. kyiv, ukranews).

The informational resource of this study is the collection of street art works created between 2010 and 2019. The collection of murals includes 160 works. This study used retrospective analysis of the history of graffiti and murals in the world and in Ukraine based on (Gastman, Neelon, 2011, Nguyen, Mackenzie, 2010, Ganz 2011, Alden, 2010, Bodnar, 2016, Kuzova, 2015, Havrylash, 2018).

In this study, we have analyzed art festivals and art projects that promote the development of modern muralism in Ukraine and, in particular, in the capital, and have found that one of the first art festivals held in the capital was Muralissimo timed to EURO 2012 football championship. Within the art festival that lasted from October 2010 to October 2011, some of the first Kyiv murals were created; they had bright colors and no proper names. The main idea of the project was to create vivid pieces of art that would liven up the capital. In total, 7 works, which are listed in Table 1, were created during the art festival.

Over the next years, the following art projects were organized: French Spring (2013), City Art (2015), Mural Social Club (2016), Art United Us (2016, 2017), Mural Social Club. Back to school! Ukraine 2017 and French Art 2019. Between 2014 and 2018, a series of murals were created within various art projects. In particular, these include the following: City Art Festival in 2015 - 13 works created, Dynamic Urban Culture Kyiv (2015) - 10 works, Mural Social Club 2016 - 16 works, Art United Us in 2016 - 27 works and Art United Us in 2017 - 11 works, respectively, Mural Social Club. Back to school! Ukraine 2017 - 4 works, French Spring 2019 - 1 mural.

As of 2019, there are 160 murals in Kyiv created by more than 35 artists from different countries. Most of the murals are in the city center, but there are some in all city districts.

There are murals created in the form of famous people's and artists' portraits and those dedicated to relevant global matters: environmental issues, fight for freedom, equality, love, appreciation of human relationships and everybody's inner world, ability to dream and appreciate life, etc. The issue of mural identification as tourism resources has been studied based on the findings of tourism studies, theoretical and methodological consideration (Liubitseva, Pankova, Stafiichuk, 2007, Kuzyk, 2010, Smal', 2010, Mal's'ka, 2012, Kvartal'nov, 2002, 2003), etc.

Results and analysis. Murals are pieces of monumental painting that are most frequently created on house walls and less frequently on the walls or roofs of industrial buildings or fencing.

The Ukrainian tradition of painting house walls with different ornaments, flowers and animals has national origins. The traditional Ukrainian 18thcentury village was notable for brightly painted huts. Obviously, modern street art objects go far beyond traditional art, but they more often cause admiration than disapproval among the public. Some bright works with attractive images of animals or fairytale characters can raise the mood and diversify old city yards, add colors and contribute to a positive impression from the surroundings.

In many people's opinion, muralism emerged in the ancient times and is associated with the creation of first paintings. However, modern murals on 
residential houses and even on educational institutions have somewhat different features. The emergence of graffiti and murals was due to the appearance of images or inscriptions by an unknown author. Graffiti and muralism were flourishing in the 1970s-80s. Nicolas Riggle (2010) calls the 1970s the "rock-n-roll years of visual art".

Graffiti (from Greek grapho - means "I write") are words or texts scribbled with a sharp object or painted on stone, wood or brick. Modern graffiti mainly include chaotic inscriptions, caricatures, unintelligible images that can figure out by artists who are engaged in their creation. This type of street art cannot be a decoration of the urban environment and rather serves as a certain challenge to society. In Ukraine, there are different types of graffiti: tags, artistic works and stenciled paintings. Graffiti are mostly percepted extremely negatively by society and do not concern our research subject. Architects often consider graffiti to be vandalic and illegal. Murals, if created without prior approval of location and theme and without agreement with the owners of building, on whose walls they are then created, are mainly treated negatively, too.

"Mural" is translated as "wall" from Spanish. Modern murals can be created using any technique and various materials. It should be noted that a type of monumental art called mosaic became widely spread in the 1960s-70s. In Ukraine, walls of houses, educational institutions and hospitals were commonly decorated with mosaic pictures. Examples include mosaics "Water is the Source of Life" in Bortnychi (34 Kharchenko St.), "Movement" on the wall of "Nauka" sports center swimming pool (32 Akademik Vernadskyy Blvd.), "Victory" on the wall of the administrative building of the National Cancer Institute (33 Lomonosova St.), mosaic "Kyi, Shchek, Khoryv and Lybid" (1 Myropolska St.), "The Triumph of Cyberneticists" on the wall of the building 6 of Glushkov Institute of Cybernetics of the National Academy of Sciences of Ukraine, etc.

Some murals in Kyiv created by the Ukrainian street artist Kostiantyn Stretutskyi also adopt the mosaic technique. These include the mosaic mural "Happy Childhood" on the crossroads of Striletska and Stritenska Streets depicting 8 child portraits (this work was one of the first that was created in the capital in 2010), the mural "Mosaic" created in 2015 at 23 Velyka Zhytomyrska St., and the mosaic mural "Chatting Dinosaur" at 118 Saksahanskyy St. in 2017. Thus, various modern street art objects, such as graffiti, murals and installations, have been appearing in Ukraine since the mid-2000s, but there is still no established definition of the notion of street art. Currently, there is a scientific discussion concerning the definition of the street art phenomenon and distinction between the notions of street art and urban art (Tylik, 2016, Grytsiuk, 2018, Havrylash, 2018, etc.). Street art (Ponosov, 2016) covers material art in the form of graffiti, installations, sculptures, murals and procedural practices (action, performance). $\mathrm{He}$ emphasizes that street art should only include creative projects and practices that interact with space and express the conceptualization of street processes and systems and not only use the city as media space. Some researchers suggest that the term of urban art should represent a general notion that includes various objects, projects and practices created in the urban space without distinctions by ideological, esthetic or technical aspects (Street-art aesthetics, 2018). The term of public art is close to urban art and means art in public space.

According to (Havrylash, 2018), typical features of murals are their plot character of composition and complicated technique. As a rule, they cover the entire wall surface and are created with the permission of municipal authorities and sometimes even to their order. Muralism is a type of modern socially oriented art shaping the urban environment. However, wall paintings are not always treated as pieces of art, but rather as a challenge to society and sometimes even as an act of vandalism. As a rule, works of art are exhibited in picture galleries and museums and are traditionally considred as world culture heritage. It can be said that they tend towards the elitist space (galleries, museums). Murals cardinally differ from paintings in terms of artistic value, technique and size. The author of street art works often remains unknown. Street artists seek to convey their ideas to society without intermediaries or spatial obstacles and not limit themselves to gallery spaces. World famous paintings are exhibited to tourists and incite strong interest in society. Most of street art works have not reached this level of recognition, so it is not correct to describe them as this type of tourism resources. Up to now, there is no unified definition of the notions of street art, monumental art, etc., which makes it more difficult to identify murals as a form of art and distinguish it as a tourism resource.

According to the Law of Ukraine "On Tourism" dated 15.09.1995, "tourism resources are tourism offers that are or can be proposed on the basis of or using state, municipal or private property." The currently applicable classifications of tourism resources most often distinguish between: natural tourism resources and socio-economical, 
anthropogenic or socio-historical ones. Sociohistorical tourism and recreational resources (Smal', 2010) include: archeological, architectural, eventbased and informational, scientific and educational, heroic and pedagogical, literature and artistic. Literature and artistic, heroic and pedagogical and scientific and educational resources belong to eventbased ones by their nature. They are mostly associated with famous people who significantly influenced history and culture of mankind.

In our opinion, it is not reasonable to consider modern murals as artistic resources judging by the
Kuzyk S. interprets the notion of tourism resources as a collection of natural and man-made objects that can be used to make tourism products. In our opinion, it is worth using murals as new alternative attractions during city tours and separate them into the group of conceptual tourism resources (see Fig. 1), which, apart from murals, includes other forms of street art, in particular, festivals and performances organized on city streets and squares.

Unfortunately, the versatility of the notion of tourism resources, which is characterized by various approaches to their functional, territorial, essence-

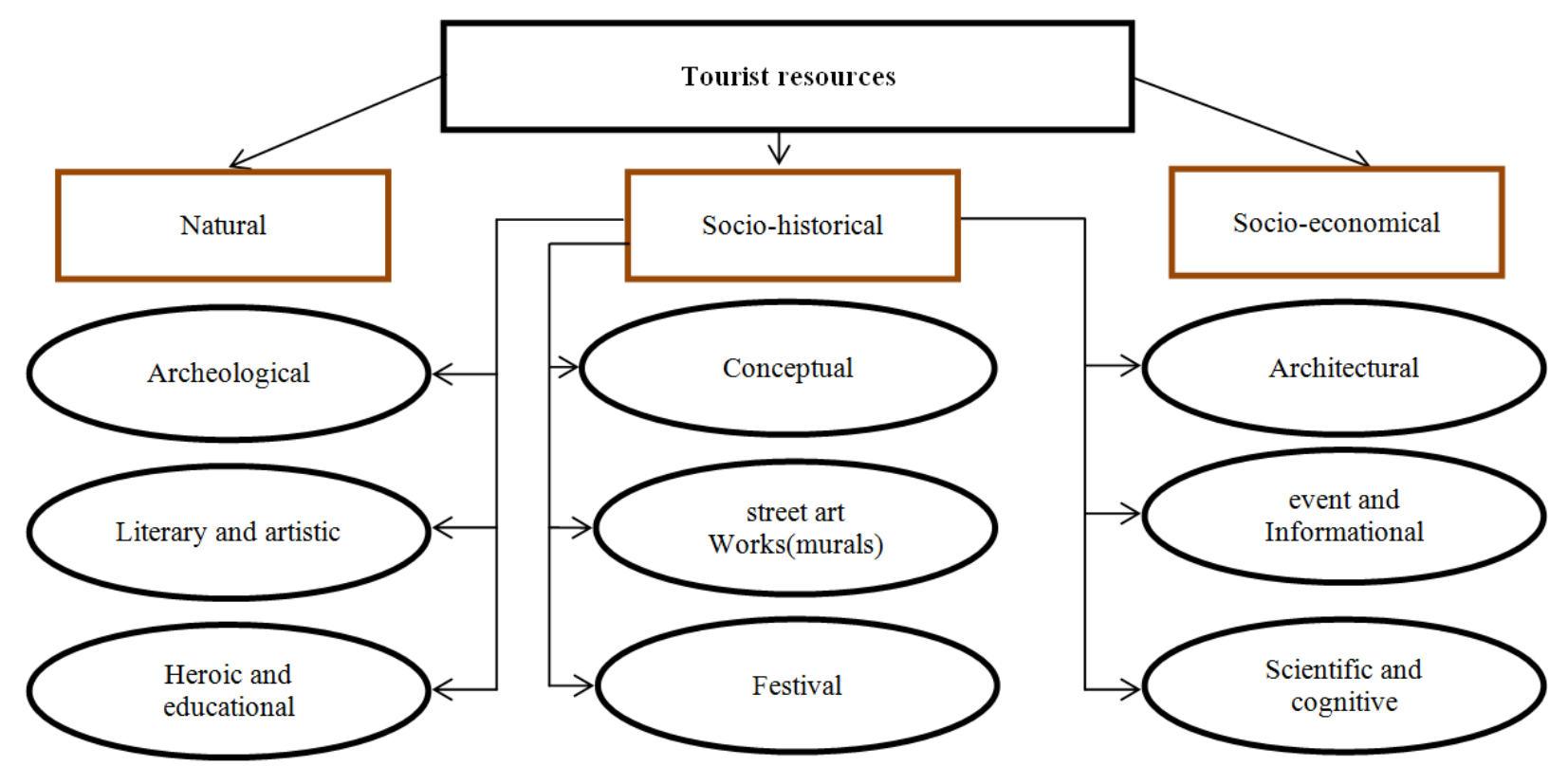

Fig. 1. Supplemented structure of tourism resources according to (Smal', 2010).

importance of the historic person or the recognition of artist in a certain domain of culture and art. Artworks include paintings, pictures in a certain style, tapestry, sculptures, etc., created by prominent artists. To some extent, the artist's personality and contribution to the world's culture and art play a role in the appreciation of these tourism resources. According to the essenceoriented approach, (Liubitseva, Pankova, Stafiichuk, 2007, Kuzyk, 2010) it is suggested to distinguish natural, infrastructural, cultural and historical tourism resources. Monumental art can fall within the category of cultural and historical resources. Tourism is one of the areas where various resources are actively searched for in order to meet tourists' needs and create qualitatively new tourism offers. In this respect, murals (wall paintings) can be of great interest. Due to the fact that some culturologists define murals as a type of monumental art, they could be identified within this category; however, no available classification of tourism resources includes murals or street art as a type of tourism resources. based, and others, only complicates the process of identifying murals as urban tourism resources.

The EURO 2012 football championship became a powerful factor for creating modern murals in Kyiv. Within the Muralissimo art festival, which lasted from October 2010 to October 2011 and was timed to the football championship, the first seven murals in Kyiv were created with the support of the authorities and Kyiv Municipal Art Gallery "Lavra". They are all listed in the Table 1. Their typical features are bright colors and absence of titles.

Another surge in the creation of murals in Kyiv was in 2014. Social and political problems in Ukraine urged artists to materialize actively their thoughts in the street art format. In 2014, 5 works were created: "Revival", "Time of Change", "Saint George", "I love Ukraine" and an unnamed patriotic wall painting created by the French artist Seth and depicting two young men symbolizing the Ukrainian coat of arms.

Wall paintings appeared in different Kyiv districts during different art projects, such as 
Table 1. Murals of Kyiv that were created during "Muralissimo" art festival

\begin{tabular}{|l|l|l|l|}
\hline Author & Year & Address & Theme \\
\hline $\begin{array}{l}\text { Interesni Kazki, (Ukraine) } \\
\text { Lodek (Ukraine) }\end{array}$ & 2010 & Lavrskyi Lane, 9 & Human running with cones in hands. Created in surrealism style \\
\hline 2Shy (France) & 2010 & Hoholivska St., 32A. & Optical illusion \\
\hline Remed (France) & 2010 & Zlatoustivska St., 20 & $\begin{array}{l}\text { Woman on boat as symbiosis of Motherland and "Kiy, Shchek, } \\
\text { Choriv and Lybid” monument }\end{array}$ \\
\hline $\begin{array}{l}\text { Interesni Kazki (Ukraine) } \\
\text { ZonenKinder (Germany) }\end{array}$ & 2011 & Dehtiarivska St., 23 & $\begin{array}{l}\text { Woman on a boat as symbiosis of Motherland and "Kiy, Shchek, } \\
\text { Choriv and Lybid" monument }\end{array}$ \\
\hline Zbiok (Poland) & 2011 & Honchara St., 9 & Problems of human relations: domination, hierarchy, etc. \\
\hline 33ttman (France) & 2011 & Lypkivskoho St., 16 & Relations between women and men \\
\hline M-city (Mariusz Waras) (Poland) & 2011 & Lavrska St., 1 & Industrial style (different mechanisms are shown) \\
\hline
\end{tabular}

French Spring and City Art in 2015, Dynamic Urban Culture Kyiv also in 2015, Mural Social Club in 2016, Art United Us 2016-2017, Mural Social Club. Back to school! Ukraine 2017. It became popular to create murals upon the orders of different public associations and with the support of Kyiv Municipal State Administration. Over the last 5 years, the number of murals in Kyiv increased to 160 works created by more than 35 artists from different countries.

A large number of murals were created in 2015 within the City Art and Dynamic Urban Culture Kyiv art projects initiated by the director and artist Geo Leros (see the Table 2).

The Sky Art Foundation was established in 2014; it actively supports the development of a new generation of Ukrainian modern artists and often organizes various art projects in Ukraine. Within the Mural Social Club festival held between 12 of May and 30 of July 2016 with the support of the Sky Art Foundation, several murals were created that were dedicated to different aspects of human relationships. They were mainly created in distant districts of the city. In particular, it is the mural "Fragment of Hope" located at 33/44 Petra Hryhorenka Ave., dedicated to the problem of violence and cruelty. It depicts two hands breaking a sword, which symbolizes opposition to violence and cruelty. A text in Braille script is encoded in this mural (hope). The mural "Love Rules the World" (8 Arkhitektor Verbytskyy St.) by the Italian artist Francesco Giorgino working under the nickname Millo, "A Girl and Sunflowers" created by the Wallstreet company and "The Earth and the Sky" by Fikos Antonios (Greece) on the walls of the house in 4 Anna Akhmatova St., the mural "The Visionary" at 1/2 Mykola Zakrevskyy St. by Fintan Magee,
"The Evolution of Life" by Oleksandr Hrebeniuk (Ukraine) at 1 Sribnokilska St., "Violinist" at 9A Zoya Haidai St. by Oleksandr Korban, etc. Some of these works are among the largest Kyiv murals listed in the Table 3. This list includes the works of both foreign and Ukrainian street artists.

In the same 2016 year, the Art United Us art project was also organized that brought about 27 murals in the capital. Among them are "Now" and "Kharkiv Area" created on the walls of a building at 158 Kharkivske shose, "The Cossacks" and "Shelter" are also painted in black and white on the walls of a building, murals "Bird" and "Treasury" in Mykola Bazhan Ave., and "Brotherhood" and "Freedom", which are among Kyiv's largest murals (see the Table 3).

Quite unusual are murals dedicated to religious aspects of life, such as "Portals" by the Spanish artist Gonzalo Borondo, who created a mural dedicated to the Ukrainian sanctuary - St. Sophia's Cathedral (16D Heroyi Stalingrad Ave.), the mural "Archangel Michael" was created by the artist Gaia (9 Mykola Bazhan Ave.), and a mural depicting Virgin Mary with little Jesus on the hands at 73/1 Peremoha Ave. The authors are the UpTown team (Ukraine).

Murals often decorate dull bedroom city districts making them more attractive. Creation of eye-catching bright paintings on the facades of multi-story buildings gives a new, more modern look to these buildings. They contribute to a better visual reception of the surroundings. Combined with landscape improvement and gardening, wall paintings create a new image of districts and make them more comfortable for leisure. All these attract more people coming to these districts in order to see art objects and have a rest and make them esthetically attractive both for locals and for tourists.

Thus, a series of murals that expose relevant issues of our times: freedom, the value of life, justice, 
Table 2. Murals created during City-Art and Dynamic Urban Culture Kyiv art projects in 2015

\begin{tabular}{|c|c|c|c|}
\hline Name & Author & Address & Project/Theme \\
\hline Lesia Ukrainka & Guido van Helten & Striletska St., 28 & City Art / Dedicated to Lesya Ukrainka \\
\hline Gymnast & Fintan Magee (Australia) & Striletska St., 12 & $\begin{array}{l}\text { City Art / Gymnast while performing a somersault. } \\
\text { Dedicated to world champion Anna Rizatdinova }\end{array}$ \\
\hline Grushevsky & Kailas-V (Ukraine) & Sichovykh striltsiv St.,75 & City Art / Portrait of the first president of Ukraine \\
\hline Carousal & M-city (Poland) & Striletska St. 20b. & $\begin{array}{l}\text { City Art / Industrial-mechanical motives were used. } \\
\text { There is a carousel of } 6 \text { cars and various parts }\end{array}$ \\
\hline The man in the shirt & Aryz (Spain) & Velyka Zhytomyrska St., 6A & $\begin{array}{l}\text { City Art / Man in unbuttoned shirt with a stick in his } \\
\text { hands }\end{array}$ \\
\hline Journalist & $\begin{array}{l}\text { Oleksandr Hrebeniuk } \\
\text { (Ukraine) }\end{array}$ & Honchara St., 24 A & $\begin{array}{l}\text { City Art / Depicts a man working on a typewriter with } \\
\text { many pieces of paper around }\end{array}$ \\
\hline Calligraphy & VikaVita (Ukraine) & Sichovykh striltsiv St., 7 & $\begin{array}{l}\text { City Art/ The inscription "Don't tell us when you stand } \\
\text { aside". The importance of friendship and support. }\end{array}$ \\
\hline Girl in embroidery & Guido van Helten (Australia) & Lesi Ukrainky Blvd., 36 B & $\begin{array}{l}\text { City Art / A girl who puts embroidery on herself and } \\
\text { looks thoughtfully into the distance }\end{array}$ \\
\hline Storks & Taras Arm (Ukraine) & Heorhiivskyi Lane, 9 & City Art/ The flight of majestic birds is depicted \\
\hline Cossack & $\begin{array}{l}\text { Francisco Rodrigues da Silva } \\
\text { «Nunca» (Brazil). }\end{array}$ & Spaska St., 6A. & $\begin{array}{l}\text { City Art/ The Cossack is depicted in Ukrainian-Brazilian } \\
\text { style, the faces of which are painted by the hands of the } \\
\text { aborigines }\end{array}$ \\
\hline The Rebuild & Fintan Magee (Australia) & Husovskoho St., 10/8 & $\begin{array}{l}\text { City Art / Environmental topics. The problem of global } \\
\text { warming }\end{array}$ \\
\hline Crossing & Fintan Magee (Australia) & Voloshska St., 19 & $\begin{array}{l}\text { City Art / Environental topics. A man with a deer in the } \\
\text { water }\end{array}$ \\
\hline $\begin{array}{l}\text { Instruction to the } \\
\text { sons of Yaroslav }\end{array}$ & Dmytro Fatum (Ukraine) & Velyka Zhytomyrska St., 196 & $\begin{array}{l}\text { City Art/ Symbolic composition dedicated to Yaroslav the } \\
\text { Wise. The painting "Instruction to the sons of Yaroslav" } \\
\text { in } 1054 \text { was used as a basis }\end{array}$ \\
\hline Girl and bird & $\begin{array}{l}\text { Taras Arm, Oleksandr Korban } \\
\text { (Ukraine) }\end{array}$ & Synoozerna St., 2A & Dynamic Urban Culture Kyiv/ Baby dreams \\
\hline Virgin Mary & Up Town (Ukraine) & Peremohy Ave., 73/1 & Dynamic Urban Culture Kyiv/ Religious topics \\
\hline Swallows & Pantonio (Portugal) & Peremohy Ave., 95 & Dynamic Urban Culture Kyiv/ Birds \\
\hline Little fashionista & Oleksandr Korban (Ukraine) & Tupoleva St., 3 & $\begin{array}{l}\text { Dynamic Urban Culture Kyiv/ Symbolic reminder of } \\
\text { children who have lack of parental attention. }\end{array}$ \\
\hline Swift & Alex Maksiov (Ukraine) & Akad. Bulakhovskoho St., 40 & Dynamic Urban Culture Kyiv/ Giant bird \\
\hline Abstraction & $\begin{array}{l}\text { Kenor Martinez Vanbergen } \\
\text { (Spain) }\end{array}$ & Peremohy Ave., 114/2 & Dynamic Urban Culture Kyiv / Abstraction \\
\hline Elephant with balls & Oleksandr Korban (Ukraine) & Tupoleva St., 7B & $\begin{array}{l}\text { Dynamic Urban Culture Kyiv/ The importance of } \\
\text { dreaming and moving towards its realization }\end{array}$ \\
\hline No Name & Zosen Bandido (Spain) & Tupoleva St., 7B & $\begin{array}{l}\text { Dynamic Urban Culture Kyiv / Motives from the works } \\
\text { of Ukrainian master Maria Primachenko }\end{array}$ \\
\hline Funny animals & Viacheslav Shum (Ukraine) & Tupoleva St., 13A & $\begin{array}{l}\text { Dynamic Urban Culture Kyiv/ Depicts a ball with funny } \\
\text { animals }\end{array}$ \\
\hline Animals-aliens & $\begin{array}{l}\text { Viacheslav Shum, Anastasiia } \\
\text { Merkulova (Ukraine) }\end{array}$ & Klavdiivska St., 22 & $\begin{array}{l}\text { Dynamic Urban Culture Kyiv/ Images of unrealistic } \\
\text { alien beasts on the wall of a higher vocational college of } \\
\text { construction and architecture }\end{array}$ \\
\hline
\end{tabular}

equality, and love were created in Kyiv in Darnytskyi, Desnianskyi, Sviatoshynskyi Districts and in Obolon. Most of them were created within the Art United Us art project in 2016 and 2017 and Mural Social Club 2016. These are five murals created on buildings situated in Mykola Bazhan Street and several more in Kharkivske shosse Street, which are among the largest in Kyiv and listed in the Table 3.

The brightest works in Sviatoshynskyi District are: mural "Swift" at 40 Akademic Bulakhovskyy St., "Position" at 22 Klavdiivska St., "Violinist" at 4B
Zholudev St., "Chester Bennington" at 22 Akademic Palladin Ave., and works at 3 Akademik Tupolev St. and 7B Horskyy St., "Dog" at 9 Vidpochynok St., "Swallows" at 95 Peremoha Ave., "Abstraction" at 114/2 Peremoha Ave., etc.

The large-scale works in Desnianskyi District are "The visionary" by Fintan Magee created on the wall of a sixteen-story building, and a mural at 16 SholomAleikhem St. by Taras Makar. The mural encodes the lyrics of the song "High Voltage" by the Australian band $\mathrm{AC} / \mathrm{DC}$ which are written in a circle, which 
symbolizes the process of infinite energy spreading.

In Obolon, a series of two murals: "Portal" and "Dancers" was created in Heroyi Stalingrad Ave. One wall depicts a dancer and the other wall depicts his partner. Both murals are executed in black and white by the Ukrainian artist Oleksandr Korban. He is also the author of "Young Violinist". One of the brightest murals in the district is "Wall-Curtain" at 29A Marshal Tymoshenko St. and "Cartoon Characters" at 33 Heroyi Dnipra St.

Ukrainian street art aims to draw public attention to crucial issues of our times and at the same time change the appearance of buildings constructed during the Soviet period that featured no architectural decorations or variety of shapes. The creation of wall paintings on such buildings adds an esthetic effect to the reception of homogenous buildings. The artistic creativity of street artists consistently changes the modern image of cities. The visualization of socially significant issues becomes a trademark not only of the capital but also of other Ukrainian cities.

In 2017 within the project Mural Social Club: Back to school! Ukraine project, several murals were created on educational institutions of the capital and other Ukrainian cities, in particular, Kremenchuk, Popasna, Cherkasy, Volnovakha and Chernihiv. The main goal is to develop children's and adults' creativity and not to stop dreaming. The motto of the festival is "A World without Clichés and Limits". 4 works were created in the capital within the project: "A Girl's Imagination" by Mono Gonzalez and Seth on the walls of Gymnasium No. 274, "Dialogue" on the walls of Gymnasium No. 267. The author of the mural is the Argentinian artist Franco Fasoli, known under the nickname JAZ. The picture represents two big cats that are standing in the middle of a forest and talking. Stripes on their bodies represent communication and signals they are sending to each other. The mural "Maturation" on the wall of the Building 7 of Kyiv Polytechnic Institute depicts how Serhiy Korolov was changing from a boy to an adult researcher. The author is Marat Morika. The diptych mural "We are together in this" by the Israeli artist KLONE was created on the wall of Kindergarten (nurcery school) No. 130 in Shevchenkisvkyi District of the capital. Murals "Dialogue" and "Mind, Body and Soul" are listed in the Best Street Art 2017, a list compiled by the website "I Support Street". The mural "Dialogue" is situated at 7 Arkhitektor Verbytskyy Street, and the mural "Mind, Body and Soul" is at 44 Verkhniy Val Street. This prestigious list of world murals includes 3 Ukrainian murals, two of which, as we have mentioned, are in Kyiv and one is in Kharkiv.
In 2018, the Ukrainian artist Vitalii Hidevan created several murals depicting animals, which is his style. These are murals "Wise Owl" at 7 Kruhlouniversytetska Str., "A Girl with a Racoon", and "Piglet". In 2019, the mural "Turtle" appeared on the walls of a kindergarten in Sofiivska Borshchahivka.

Quite unusual is the creation of murals on the walls of public institutions and organizations. There are such works in Kyiv. In 2017, the world's first mural on a police station appeared in Pechersk District at 30 Moskovska St. "Rise up in the dirt" was created by an artist from New York having nickname BKFox within the Art United Us project. The mural represents hands that help a flower grow from under a pile of waste. The mural of Darnytsia District Administration in Kyiv symbolizes that the authorities must serve their people and public officials must be humane and open.

Murals dedicated to historical figures, prominent musicians and important events in the form of portraits are of great interest. They include the murals made by Andrii Palval: the portraits of Mykhailo Hrushevskyi (75 Sichovych Striltsiv St.) and Pavlo Skoropadskyi (12 Starovokzalna St.), "Kruty" (111/113 Velyka Vasylkivska St.), and Serhii Nihoian's portrait (22b Mykhailivska St.) executed by the Portuguese artist VHILS, a cinema mural at 22/17 Kostiantynivska St. depicting 8 portraits of prominent cinema celebrities and a picture of a camera, in particular portraits of Serhii Paradzhanov, Leonid Bykov, Bohdan Stupka, Quentin Tarantino, actors Jack Nicholson, director Martin Scorsese, actresses Ada Rohovtseva and Meryl Streep, and a mural with John Paul II, etc.

Works dedicated to the environmental issues, in particular climate change, are also of great interest: these are murals by Fintan Magee "The Rebuild" (10/8 Serhiy Husovskyy St.) and "Crossing" (19 Voloshska St.), "Time of Change" by the art duet Interesni Kazki (4 Striletska St.), "Sperm Whale" at 147/5 Saksahanskyy St. by the art duet Nevercrew (Switzerland) and "The Lynx of Zakarpattia" (16/1 Azerbaidzhanska St.) by the Ukrainian artist Vitalii Hidevan working under the nickname Gide1, as well as two murals in surrealistic style on the facilities of the Kyivvodokanal company (on Vinohradar) by Dima Fatum (Ukraine).

The large-scale art project of national unity "MoreThanUs" was presented at Osokorky metro station in Kyiv in 2018. Artists from seven countries and Ukraine created eight murals. All paintings were devoted to the national unity of Ukraine. The Brazilian artist Apollo Tores created the mural "Universal Language". Music is a universal language that united dif- 
Table 3. The largest murals in Kyiv

\begin{tabular}{|c|c|c|c|c|}
\hline Name & Year & Author & Address & Project/Theme \\
\hline Renaissance & 2014 & $\begin{array}{l}\text { Julien Malland "Seth" (France), } \\
\text { Oleksii Kyslov (Ukraine) }\end{array}$ & Borychiv Tik St., 33/6A & $\begin{array}{l}\text { French Spring / The process of national } \\
\text { identity of Ukraine }\end{array}$ \\
\hline Protectress & 2016 & Mata Ruda (Costa Rica) & Tarasa Shevchenka Lane, 1 & Art United Us/ Shore - Goddess of good \\
\hline $\begin{array}{l}\text { Life without science is } \\
\text { death (Vita Sine Litteris } \\
\text { Mors Est) }\end{array}$ & 2013 & $\begin{array}{l}\text { Volodymyr Manzhos (Ukraine), } \\
\text { Julien Malland «Seth» (France) }\end{array}$ & Illinska St., 4A & $\begin{array}{l}\text { French Spring / The world of inventions is } \\
\text { depicted. }\end{array}$ \\
\hline Mosaic & 2015 & Kostiantyn Strytutskyi (Ukraine) & Velyka Zhytomyrska St., 23 & $\begin{array}{l}\text { Theme is love for your hometown. Depicts } \\
\text { children drawing Kiev in the form of a } \\
\text { female face. }\end{array}$ \\
\hline Earth and sky & 2016 & Ficos Antonios (Greece) & Akhmatova St.,4 & $\begin{array}{l}\text { Mural Social Club/ Byzantine fresco style } \\
\text { image. Man and woman symbolizing Earth } \\
\text { and Sky }\end{array}$ \\
\hline Little girl in sunflowers & 2016 & Wall street (Ukraine) & Akhmatova St., 4 & Mural Social Club/ Patriotic topics \\
\hline Maze of problems & 2016 & Rustam QBic (Russia) & Dmytrivska St., $62 / 20$ & $\begin{array}{l}\text { Art United Us/ The problem of choosing the } \\
\text { path to solve life's problems }\end{array}$ \\
\hline Swallows & 2015 & Pantonio (Portugal) & Peremohy Ave., 95 & Dynamic Urban Culture Kyiv/ Abstraction \\
\hline Bird & 2016 & Ernesto Maranje (USA) & Mykola Bazhan Ave., 5 E & Art United Us/ Abstraction \\
\hline Treasury & 2016 & Ernesto Maranje (USA) & Mykola Bazhan Ave., 5 & $\begin{array}{l}\text { Art United Us/ The inner world of man is } \\
\text { symbolically shown. }\end{array}$ \\
\hline Bird of flowers & 2016 & Ernesto Maranje (USA) & Lesya Ukrainka Blvd., 5 & Art United Us/ Abstraction \\
\hline Freedom & 2016 & Aleks Maksiov (Ukraine) & Ivan Franko St., 12 & Art United Us/ The problem of human choice \\
\hline The visionary & 2016 & Fintan Magee (Australia) & Mykola Zakrevskyy St., 1/2 & Mural Social Club/ Environmental topics \\
\hline Time of changes & 2014 & Interesni Kazki (Ukraine) & Striletska St.,4-6 & $\begin{array}{l}\text { Struggle for freedom and independence of } \\
\text { Ukraine }\end{array}$ \\
\hline Love rules the world & 2016 & $\begin{array}{l}\text { Millo (Francesco Giorgino) } \\
\text { (Italy) }\end{array}$ & $\begin{array}{l}\text { Arkhitektor Verbytskyy } \\
\text { St., } 8\end{array}$ & $\begin{array}{l}\text { Mural Social Club/ the symbolic image of } \\
\text { the young man who controls the key to a } \\
\text { heart }\end{array}$ \\
\hline Instability & 2016 & INO (Greece) & Mykola Bazhan Ave., 7 & $\begin{array}{l}\text { Art United Us/ Problems of instability of the } \\
\text { modern world }\end{array}$ \\
\hline Archangel Michael & 2016 & Gaia (USA) & Mykola Bazhan Ave., 9 & $\begin{array}{l}\text { Art United Us / Problems of military } \\
\text { aggression and informational war }\end{array}$ \\
\hline Mother and daughter & 2016 & $\begin{array}{l}\text { James Reka (RekaOne) (Aus- } \\
\text { tralia) }\end{array}$ & Mykola Bazhan Ave., 93 & $\begin{array}{l}\text { Art United Us/ mural diptych (mother's love } \\
\text { for daughter) }\end{array}$ \\
\hline Care «El Cuidado» & 2016 & Liqen (Spain) & Bratyslavska St, 12 & Art United Us/ Protection and care of men. \\
\hline Bicyclist & 2016 & Emmanuel Jarus (Kanada) & $\begin{array}{l}\text { Viacheslav Lypynskyy St., } \\
13\end{array}$ & The importance of sport in people's lives \\
\hline Liberty & 2016 & 2501 (Italy) & Maiakovskyy Ave., 1V & $\begin{array}{l}\text { Art United Us/ the word "Liberty" is } \\
\text { encrypted }\end{array}$ \\
\hline Herald of life & 2015 & Oleksandr Brits (Ukraine) & Reitarska St., 7B & $\begin{array}{l}\text { It shows a flock of black crows and one } \\
\text { white who represents dissimilarity to others } \\
\text { and is a symbol of good news. }\end{array}$ \\
\hline Brotherhood & 2016 & Dourone & Kharkivske shose St.,180/21 & Art United Us/ Respect, freedom, diversity \\
\hline Now & 2016 & Innerfields (German) & Kharkivske shose St., 158 & $\begin{array}{l}\text { Art United Us / girl hugs the ghost of a loved } \\
\text { one with an arrow in the back }\end{array}$ \\
\hline $\begin{array}{l}\text { Surrealistic drawing about } \\
\text { the Kharkov massif }\end{array}$ & 2016 & Dima Fatum (Ukraine) & Kharkivske shose St., 158 & $\begin{array}{l}\text { Art United Us/The history of the Kharkiv } \\
\text { residential area of the capital is depicted }\end{array}$ \\
\hline The world - Love is Ours & 2015 & San Miguel «Okuda» (Spain) & $\begin{array}{l}\text { Akademic Vernadskyy St., } \\
87\end{array}$ & $\begin{array}{l}\text { Dynamic Urban Culture / The struggle of } \\
\text { nature and man-made load }\end{array}$ \\
\hline Shelter & 2016 & Paola Delfin (Mexico) & Kharkivske shose St., 170 & $\begin{array}{l}\text { Art United Us/ Despite the difficulties in life, } \\
\text { everyone has a shelter, a home to return to }\end{array}$ \\
\hline Cossacks & 2016 & Oliver Bonnard (Kanada) & Kharkivske shose St., 170 & $\begin{array}{l}\text { Art United Us/ The role of Cossacks in the } \\
\text { development of Ukraine and anthropogenic } \\
\text { impact on the Black Sea }\end{array}$ \\
\hline Wall curtain & 2014 & Anozer studio (Ukraine) & $\begin{array}{l}\text { Marshal Tymoshenko St., } \\
\text { 29-A }\end{array}$ & $\begin{array}{l}\text { 3D Mural. Shown is a curtain with windows } \\
\text { and balconies and a boy opening this curtain } \\
\text { that shows the boundless world outside the } \\
\text { house }\end{array}$ \\
\hline The impact of Discovery & 2016 & Li-Hill (Kanada) & $\begin{array}{l}\text { Peremohy Ave.,37 } \\
\text { CCA KPI }\end{array}$ & $\begin{array}{l}\text { Mural Social Club/ Depicts the great } \\
\text { discoveries of humanity by the Higgs boson } \\
\text { and chronography }\end{array}$ \\
\hline Mind, body and soul & 2017 & Kraser (Italy) & Verkhnii Val St., 44 & $\begin{array}{l}\text { Art United Us/ Confrontation of the inner } \\
\text { world of man with the outside world }\end{array}$ \\
\hline
\end{tabular}


ferent sides of the conflict during the events on Maidan in February 2014. The mural depicts a piano that was standing in front of police officers. The Spanish artist Kraser in his work "Motherland" used images of animals from the Red Book of Ukraine - a bear from Western Ukraine and a kite from the east of the country. At the background of the animals there are silhouettes of Lviv Townhall and Donetsk Airport and there is the Ukrainian coat of arms in the form of traffic lights between them. The Belgian artist Sper created the painting "Knowledge is a Treasure", which depicts the schoolteacher and ATO hero Volodymyr Donos. The Swiss artist Jasm One created a mural with Bohdan Stupka's portrait at the background of the Carpathian Mountains and Donetsk spoil tips with the inscription "United", which symbolizes culture uniting all of us. The American artist BKFoxx in his work "Unfinished" created a stained-glass image of a girl who allegedly puts herself together from pieces. This image personifies Ukraine's path to self-identification. The Belgian artist Metthew Down used a real photo of Avdiivka as a basis for his work - this town was ruined due to war actions. There is a child's painting in red color over the photo, which symbolizes different reality when future generations will have to recover from the consequences of war. The Costa Rican artist Mata Ruda in his mural "Autonomy" depicted a young Crimean Tatar woman in traditional apparel, who symbolizes the past and the present of the Crimean Peninsula. The Ukrainian Oleksandr Britsev in his work "Self-Woven" depicted a girl weaving a carpet with an outline of Ukraine. This large-scale piece of art deserves the attention not only of city locals but also of numerous tourists. The involvement of foreign artists to numerous projects in Ukraine contributes to their popularization at the international level.

In March 2019, the Ukraine's first mural with augmented reality appeared in Kyiv on the façade of Boarding School No. 13 (106B Novopolov St.). The author of this work is Vitalii Hidevan. The 12-meter mural depicts a house with a hummingbird. Using the JiliviAr app for smartphones, the image on the wall comes to life.

In April 2019, a mural on two walls of School No. 106 in Kyiv was created within the French Spring art festival. The work was executed by the French artist GooddoG. It is dedicated to instability and fragility of the world.

Now, the interactive map shows almost all Kyiv murals, but it is quite overwhelming and does not group murals by topics.

In the $21^{\text {st }}$ century, thanks to the development of mass media and the use of Internet and social networks, the boundaries between mass culture and elitist art are disappearing, which makes the last one available for general public. However, murals are not always considered to be works of art in the traditional understanding because, unlike artists who are the main motivation for people to get to see his works and are well-known as representatives of certain styles, such as classicism, modernism, etc., the creators of murals often remain anonymous. Some works of street art may exist without any information about the time of their appearance or an author.

In order to trace the change of urban environment under the influence of street art, we propose a route for visiting Kyiv murals. In developing of our route, we selected representative murals executed in different styles and dedicated to several topics: landmarks of the Ukrainian history, competition between the good and the evil, friendship and devotion, freedom and equality. The aim of the tour is to see murals that reflect important interaction problems in modern society and alter the architectural and cultural image of the city. The tour is called "Kyiv's modern street art".

The excursion mainly focuses on familiarization with the works of modern street artists that raise such important social needs as relationships in family and between people, events on Maidan in 2014, environmental issues, social values: freedom, equality, and life. The tour is intended for people who are interested in alternative tourist attractions of the capital that help trace the changes in the urban environment under the influence of street art. The main target group are people above 16 years of age. Our tour starts from the mural "Hrushevskyi" at 75 Sichovych Striltsiv St. and finishes with the mural "Protectress" at 1 Taras Shevchenko Lane. The total length of the route is 7.1 $\mathrm{km}$. It includes 24 spots. This is a walking route. The estimated time of the tour is 2 hours.

Optionally, the excursion may also include visiting the murals at the Osokorky metro station after passing the main part of the route.

Observation point No. 1 - 75 Sichovych Striltsiv St. Name - "Hrushevskyi", author - Ukrainian team Kailas-V. The mural is dedicated to $150^{\text {th }}$ anniversary of the prominent Ukrainian historian and the first President of Ukraine Mykhailo Hrushevskyi and was created within the City Art project in 2015.

No. 2 - 7 Sichovykh Striltsiv St. "Calligraphy" created by Ukrainian female artists working under the nickname VikaVita. These are sisters Viktoriia and Vitalina Lopukhina. The mural shows inscriptions "Don't say we if you stand aside..." in three languages. The main idea of the mural is to show that letters turn into ornaments and a certain texture that is 
a continuation of the sound of city streets, rhythm and pulse. The main aim is to show that, in order to see the text and understand its meaning, one should stop for a couple of minutes and thus interrupt the usual rhythm of city life.

No. 3 - 38 Velyka Zhytomyrska St. "Saint George". Authors - Ukrainian duet "Interesni Kazki". The work was created in 2014 under the influence of such events as the annexation of the Crimea and war actions in Donbass. Saint George is depicted as a Ukrainian Cossack, with a falcon face, holding a mace in his left hand and a sword in his right hand that cuts off the hands of an evil dragon that encroaches on foreign lands.

No. 4 - 23 Velyka Zhytomyrska St. "Mosaic". Author is Kostiantyn Skrytutskyi. Year of creation is 2015. The mural portrays children using crayons to draw a woman's face associated with Kyiv. The author wanted to show that the new generation of Kyiv citizens has a careful and loving attitude to their city. The top of the mural shows a girl in a "vyshyvanka" and two psalms and 10 commandments that can be read only in the dark - they are not visible in the daylight. The work has a very profound meaning and complicated technique.

No. 5 - 24B Velyka Zhytomyrska St. "Wall'na soul". Author is O'Prime. (Oleksii Pryimak, Ukraine). The work is dedicated to the issue of street art legalization. The main focus of the work is that artists exist and walls don't. It is based on the Renaissance style; there are "angels" - beginner artists - on the left and "gods" - professional artists on the right; there is a fight between artists and the authorities, which are shown as a stronger person (more power, so feeling stronger). Artists who cannot fulfil themselves, "lose their wings".

No. 6 - 9 Olesia Honchara St., author - Zbiok (Slawomir Czajkowski, Poland). It is one of the first murals in the capital created in 2011 within the Muralissimo festival.

No. 7 - 13/4 Stritenska St. On the crossroads of Stritenska and Oles Honchar Streets, there is the mural "Ukraine Forever", author - O'Prime (Oleksii Pryimak, Ukraine). The mural was executed in the Petrykivka painting style in 2014.

No. 8 - 24A Oles Honchar St. "Journalist", author - Oleksandr Hrebeniuk (Ukraine). The mural is dedicated to the journalists' work. It shows a person working at the typing machine with a lot of papers around. The work was created in 2015 within the City Art project.

No. 9 - 36A Olesia Honchara St. Untitled, author - Sebastian Velasko (Spain). The foreground of the mural shows a person, the background shows a city at night. The author was impressed with the Ukrainian capital at night, so he decided to portray it in his work. It was created in 2016 within the Art United Us project.

No. 10 - 147/5 Saksahanskyy St. "Sperm Whale". Author - art duet Nevercrew: Christian Rebecchi and Pablo Togni (Switzerland). The work is dedicated to the environmental protection, in particular to the disappearance of sperm whales. The mural was created in 2017 within the Art United Us project.

No. 11 - 12 Starovokzalna St. "Skoropadskyi". Authors - Kailas-V group (Ukraine). The work is dedicated to the Ukrainian public, political and civic figure, Hetman P.P. Skoropadskyi. The mural was created in 2015 not far from the railway station in order to emphasize historical events that took place there in 1918 and were associated with Hetman Skoropadskyi.

No. 12 - 1/90 Turhenievska St. "El Abrazo de Sosiego", author - Anna Maria (Puerto Rico), a girl and two pelicans are showm.

No. 13 - 13 Viacheslav Lypynskyy St. "Bicyclist", author - Emmanuel Jarus (Canada). A selfportrait of the artist created in 2016 not far from a cycle track. The mural is among the largest ones in the capital (see the Table 3 ).

No. 14 -2/16 Viacheslav Lypynskyy St. The untitled mural shows several playgrounds with carefree children playing on them. The playgrounds are among small houses on green hills. The image is very positive and perfectly reflects the topic of happy childhood.

No. 15 - 12 Ivan Franko St. "Freedom", author - Alex Maksiov (Ukraine). The 18-meter-high mural shows a tomtit hanging on a lamp. A lamp with a window is a conventional portal between mere mortals and freedom. The mural is among the largest ones in the capital.

No. 16 - 28 Striletska St. "Lesia Ukrainka", author - Guido van Helten (Australia). The mural shows the poetess with lilies of the valley at the bottom. The mural was inspired by the poetess' works, in particular by her poem "Lilies of the valley".

No. 17 - 20 B Striletska St. "Carousal", author Mariusz Varas. The mural was created within the City Art project in 2015 in the industrial style.

No. 18-9 Heorhiivskyi Lane. "Storks", author is Taras Arm (Taras Dovhaliuk, Ukraine). It was created within the City Art project in 2015.

No. 19 - 12 Striletska St. "Gymnast", author Fintan Magee (Australia). It shows a gymnast when she is doing a somersault. The work is dedicated to the world champion Hanna Rizatdinova. 
No. 20 - 4-6 Striletska St. "Time of Change", author - Volodymyr Manzhos from the "Interesni Kazki" art duet. Created in 2014, it shows a sixhanded Cossack fighting a snake that is winding around the Earth, with burning tires and a tank at the background. The main motif of the work is the fight between the good and the evil and the patriotic spirit of Ukrainians fighting for freedom.

No. 21 - 6A Velyka Zhytomyrska St., untitled author Aryz (Spain), created within the City Art project in 2015. It shows a man with a cudgel in the hand.

No. 22 - 24A Mykhailivska St. "B. B. King”, author is unknown. The work was created not far from a blues bar in 2016, a year after the death of B.B. King, the King of the Blues.

No. 23 - 22B Mykhailivska St. "Serhii Nihoian", author - Oleksandr Farto, having nickname Vhils (Portugal). It is a portrait of the Heavenly Hundred hero who was posthumously awarded with the title of the Hero of Ukraine and the Golden Star order. The mural is literally coined on the building wall.

No. 24 - Taras Shevchenko Lane, "Protectress", author - Ruda (Costa Rica). The mural was created near Maidan Nezalezhnosti after the 2014 events. It shows a protectress - a goddess from the Slavic mythology. We all hope for the resolution of difficult political and economic problems of Ukraine and believe in the power of the Protectress who defends Ukrainians' peace. Our route ends with a hope for bright future.

Thus, we can state that urban environment is undergoing constant changes with new art objects encouraging social and cultural transformations. The surrounding urban space is able to influence and change the consciousness of locals and tourists. The ideas of improving the urban environment using murals is gaining in popularity in many Ukrainian cities, such as Kyiv, Odesa, Lviv, Ivano-Frankivsk and others, which affects the forming of interaction between city and people as well as between separate representatives of society. All urban environment objects without exception, including murals, exist as elements of historical events and to some extent reflect the historical "text".

Conclusions. The conducted analysis demonstrated strong development of the modern muralism in Ukraine since the 2000s. The main factors that contributed to the intensive creation of murals in the country and in the capital in particular are art projects and art festivals that were organized with the support of civil activists and authorities after 2010 .

There is currently a tendency of increasing the interest of foreign and Ukrainian artists to the creation of new murals in different Ukrainian cities. As of 2019, a total number of murals in Kyiv created by 35 artists from different countries make 160. Since 2010, much attention has been paid to the creation of murals in the central part of the city, but with time they also decorated the so-called "grey" bedroom districts such as Sviatoshyno, Darnytskyi, Desnianskyi, Solomianskyi, Obolon, etc. Murals are in all Kyiv districts now. In the process of research, we have identified 32 largest murals in Kyiv.

Murals in bedroom districts improve the visual appearance of residential areas with many buildings created in the Soviet period that had no architectural decorations or diversity of forms. The creation of murals on the facades of such buildings adds an aesthetic effect to the reception of uniform buildings. The artistic creativity of street artists is definitely changing the modern image of cities. The visualization of socially significant problems becomes a trademark of both the capital and other Ukrainian cities.

One of the important goals of murals is forming of tourist motivation. High concentration of murals in the city center motivates the creation of a separate route. At the same time, the creation of murals in the historical part of the city definitely influences the development of new symbols (indicators) of the city and adds new symbolic meaning to the urban space. Therefore, involving such resources in the organization of tourist routes allows capital locals and guests to follow the changes of the urban environment under the influence of street art.

\section{References}

Bacharach, S., 2015. Street Art and Consent. The British Journal of Aesthetics, V 55(4), 481-495, https:// doi.org/10.1093/aesthj/ayv030

Back to School: vidomi khudozhnyky $\mathrm{z}$ usoho svitu namaliuvaly muraly na ukrainskykh shkolakh, 2017 [Famous artists from all over the world have painted murals on Ukrainian schools] https:/ukranews.com/ua/news/513319-backto-school-vidomi-khudozhnyky-z-usogo-svitunamalyuvaly-muraly-na-ukrainskykh-shkolakh (in Ukrainian).

Bodnar, Yu. 2016. Dvir mystetstva: de ziavyvsia, yak rozvyvavsia i kudy pryishov strit-art [Art yard: where it appeared, how developed and where street-art came] Retrieved from - https://streetheroes.platfor.ma/street-art-history/ (in Ukrainian).

Estetika strit-arta: sbornik statej, 2018 [Street-art aesthetics: collection of articles]. Saint Petersburg State University of Industrial Technology and Design. - SPb. SPbSUITD. (in Russian) 
Gastman, R., Neelon, C. 2011. The history of American graffiti - Harper Design.

Gastman, R., Neelon, C., Smyrski, A. 2007. Street world: Urban Art and Culture from Five Continents. -Harry N. Abrams.

Gavryliuk, B. 2018. Ukrainskyi mural-art u konteksti svitovoho mystetstva [Ukrainian mural in terms of global art] Bulletin of the Lviv National Academy of Arts. (37). 241-254. (in Ukrainian)

Guinard, P., Margier, A. 2018. Art as a new urban norm: Between normalization of the City through art and normalization of art through the City in Montreal and Johannesburg. Cities (77) 13-20 doi.org/10.1016/j.cities.2017.04.018

Havrylash, I. 2018. Mural-art u konteksti masovoi kultury XXI stolittia [Mural art in the context of the mass culture of the 21 st century] Issues in Cultural studies. (34) 133-142. doi.org/10.31866/24101311.34.2018.154059 (in Ukrainian)

Havrylash, I. 2018. Muraly ta hrafiti v suchasnii Ukraini: osoblyvosti ta vidminnosti [Murals and graffiti in modern Ukraine: features and differences]. Culture of Ukraine (62). 235-244. doi org/10.31516/2410-5325.062.23 (in Ukrainian)

Hrytsiuk K. 2018. Muraly: novyi pidkhid do staroho mystetstva [Murals: New approach to the old] Retrieved from https://theoutlook.com.ua/article/5056/ murali-novij-pidxid-do-starogo-mistetstva.html (in Ukrainian)

Kosova, O. 2019. Istoriia z tryvymirnym efektom: mural «Kruty» zaversheno. [History with 3-dientional effect: mural "Kruty" is done.] Vechirnii Kyiv 18. 01. 2019. Retrieved from https://vechirniy.kyiv. ua/news/istoriya-z-tryvymirnym-efektom-muralkruty-zaversheno (in Ukrainian)

Kuzyk, S. 2010. Teoretychni problemy turyzmu: suspilnoheohrafichnyi pidkhid. [Theoretical problems of tourism: socio-geographical approach] Monohrafiia. Lviv: LNU im. Franka. (in Ukrainian)

Liubitseva, O.O. Pankova, Ye.V., Stafiichuk, V.I. 2007.Turystychni resursy Ukrainy [Tourist resources of Ukraine] Navchalnyi posibnyk. K.: Alterpres (in Ukrainian)

Moldoveanu, M. and Franc, V. 2014. Urban regeneration and more opportunities for artistic expression and cultural consumption. Procedia Economics and Finance (8), $490-496$.

Muraly Kyieva. Interaktyvna karta [The murals of Kyiv] Interactive map. Retrieved from: http://kyivmural com/uk/index
Omar S.S, Dr. Sakip SRM, Akhir N.M. 2016. Bringing the New to the Old: Urban Regeneration through Public Arts. Procedia- Social and Behavioral Sciences. (234). 515-524.

Pamiatky Ukrainy [Sights of Ukraine] Retrieved from: https://zeft.in.ua/filter/?_sft_category=murali (in Ukrainian)

Pilikin D.G. 2018. Terminologija ulichnogo iskusstva. Opyt slovarnyh definicij. [Street art Terminology. Experience vocabulary definitions] Aesthetics of street art: a collection of articles. St. Peterburg: $\mathrm{SPb}$. SPbSUITD. 4-9 (in Russian)

Riggle, N. A. 2010. Street Art: The Transfiguration of the Commonplaces. The Journal of Aesthetics and Art Criticism. Vol. 6. 248-257 https://doi/ abs/10.1111/j.1540-6245.2010.01416.x

Sakip, SRM, Bahaluddin, A., Hassan, K. 2016. The Effect of Mural on Personal Crime and Fear of Crime. Procedia - Social and Behavioral Sciences (234). 407-415.

Shakter, R. 2018. Svitovyi atlas vulychnoho mystetstva i hrafiti [World Atlas of Street Art and Graffiti]. Kyiv: Magenta Art Books (in Ukrainian)

Smal,' I.V. (2010). Turystychni resursy svitu [Tourist resources of the word] Nizhyn: Publisher of Nizhyn Mykola Gogol State University. (in Ukrainian)

Tylik, A. 2016. Ulichnoe isskustvo: opyt jesteticheskogo analiza [Street art: the experience of esthetic analysis] Avtoreferat dissertacii na soiskanie uchenoj stepeni kand. filosof. nauk special'nost' 09.00.04Aesthetics. St. Petersburg State Un-t. SPb. (in Russian)

U Kyivskomu metro prezentuvaly visim muraliv 2018 . [Eight murals presented in the Kyiv subway]. Retrieved from: https://www.ukrinform.ua/rubrickyiv/2603820-u-kiivskomu-metro-prezentuvalivisim-muraliv.html (in Ukrainian)

V Kieve poyavilsya edinstvennyj v mire oficialnyj mural na policejskom uchastke 2017 [The only one official mural in the world appeared on the police-station In Kyiv]. Retrieved from: https://kiev.informator. ua/2017/11/21/v-kieve-poyavilsya-edinstvennyjv-mire-ofitsialnyj-mural-na-politsejskomuchastke (in Russian)

Waclawek, A. 2011. Graffiti and Street Art.- London. Thames \& Hudson

Zakon Ukrainy Pro turyzm vid 15.09.1995 № 324/95-VR [The law of Ukraine on tourism]. Retrieved from: https://kodeksy.com.ua/pro_turizm/statja-3.htm (in Ukrainian) 